\title{
BEZPEČNOSTNÍ ASPEKTY IRÁCKÉ IMIGRACE DO ČESKÉ REPUBLIKY
}

\section{SECURITY FEATURES OF IRAQI IMMIGRATION INTO THE CZECH REPUBLIC}

\author{
Michael MURAD*
}

\begin{abstract}
Abstrakt
Článek se věnuje imigraci z Iráku do České republiky. Hlavním cílem je identifikace a přiblížení možných bezpečnostních hrozeb a rizik s imigrací z Iráku spojených a jejich následná analýza. Představena je i malá, relativně integrovaná a v mnohém specifická komunita Iráčanů žijících v České republice. Nejvýznamnějši hrozbu, která může s Iráčany souviset, představuje na základě analyzovaných zdrojů ohrožení národní bezpečnosti pramenící z jejich možných kriminálních aktivit. Asi nejdiskutovaněǰ̌š nebezpečí, které je dáváno do souvislosti s imigrací lidí z muslimských států, terorismus, není pro Českou republiku prozatím príliš aktuální.
\end{abstract}

\begin{abstract}
This paper is devoted to analyzing the nature of immigration from Iraq to the Czech Republic. Its primary aim is to identify main security threats connected with the immigration from Iraq and consequential analysis of risks that Iraqis can represent for the Czech Republic. The very small and quite well integrated and specific minority of Iraqis living in the Czech Republic is also analysed in detail in this essay. The main threat that can be posed by Iraqi immigration into the Czech Republic is a threat to the national security based on their criminal activities. Probably the most publicly discussed threat connected with the so-called Muslim immigration into Europe - terrorism, is not so topical in the Czech Republic at this moment.
\end{abstract}

\section{Klíčová slova}

Irák, Československo, Česká republika, migrace, imigrace, hrozba, riziko, národní bezpečnost, integrace přristěhovalců.

\section{Keywords}

Iraq, Czechoslovakia, Czech Republic, Migration, Immigration, Threat, Risk, National Security, Integration of Immigrants.

$$
* * *
$$

\section{ÚVOD}

Tématem článku je představení hrozeb a rizik plynoucích z příchodu imigrantů z Iráku pro Českou republiku, následně pak jejich analýza. S Irákem, státem, který prošel ve svých moderních dějinách mnoha zvraty, pojí Českou republiku dlouhodobé a povětšinou přátelské vztahy sahající až do období první republiky. A právě výsledkem těchto dlouhodobých vazeb je vytvoření nepř́iliš početné komunity Iráčanů, kteří nalezli v České republice svůj nový domov. Tato pospolitost, i přes současný zvýšený zájem o přistěhovalce z muslimských zemí, ovšem není v české odborné literatuře př́liš zmapována, což může být dáno kromě její malé početnosti i její malou vnější nápadností. ${ }^{1}$

\footnotetext{
*E-mail: murad@fss.muni.cz.
} 
Migraci lze dělit na migraci dobrovolnou a vynucenou. Podle kritéria doby trvání pobytu migranta v zahraničí pak na nezvratnou, spojenou se záměrem trvalého usídlení migrantů v cílové zemi, a cyklickou, kdy je návrat do domovské země předpokládán. Dále můžeme rozlišit migraci dle motivace migrantů na pracovní (ta má převážně zvratný charakter) a ekonomickou (ta do značné míry souvisí s migrací pracovní, zahrnuje ovšem i např migraci podnikatelů s cílem realizovat $\mathrm{v}$ hostitelské zemi podnikatelské záměry). A stejně tak je důležité rozlišovat migraci nelegální, která se stále více mění ve vysoce lukrativní podnikání zločineckých struktur, a migraci legální. ${ }^{2}$

Nejprve bylo nutné hrozby, které mohou být s přítomností Iráčanů spojené, v rámci teorie identifikovat. V případě, že hovoříme o migraci jakožto bezpečnostní hrozbě, je nutné rozlišit, na koho či co se tato hrozba vztahuje. Existují tři hlavní koncepty klasifikování této bezpečnosti a) národní bezpečnost, b) regionální bezpečnost, c) human security. ${ }^{3} \mathrm{~V}$ této práci je pozornost upřena na národní bezpečnost České republiky. Pojmy hrozba a riziko, které byly v české odborné literatuře užívány mnohdy nesprávně, jsou chápány dle Zemana, kdy hrozba představuje fenomén, který může nebo chce poškodit konkrétní hodnotu nezávisle na vůli. Závažnost hrozby je úměrná povaze hodnoty a toho, na kolik si danou hodnotu ceníme. Termín ohrožení je synonymem. Oproti tomu riziko je pravděpodobnost, že dojde ke škodlivé události, která postihne danou hodnotu. Riziko je závisle proměnné a lze jej určit či odhadnout tzv. analýzou rizik. ${ }^{4}$

Cílem článku je ověření či vyvrácení následující hypotézy. Ta byla formulována jako explorativní, s ohledem na to, že jde o první výzkum na dané téma. Domnívám se, že Iráčané žijící $v$ České republice nepředstavují v současnosti závažnou bezpečnostní hrozbu pro národní bezpečnost České republiky.

V rámci empiricko-analytického přístupu byly při zpracovávání článku využity následující metody: expertní šetření, standardizovaný rozhovor s účastníky - se zástupci komunity Iráčanů žijících v České republice, obsahová analýza primárních a sekundárních zdrojů a analýza statistických údajů. ${ }^{5} \mathrm{Na}$ bezpečnostní aspekty imigrace z Iráku byl tázán i důstojník z Útvaru pro odhalování organizovaného zločinu Policie ČR. Všechny rozhovory byly zaznamenány na diktafon a následně přepsány. Statistické údaje byly získávány převážně z veřejných zdrojů, přičemž byl kladen důraz na získání co nejaktuálnějších dat, zároveň ale bylo nutné informovat se u různých institucí - příslušných odborů Ministerstva vnitra ČR a Ministerstva školství, mládeže a tělovýchovy.

\section{MIGRACE JAKO BEZPEČNOSTNÍ HROZBA}

V současných debatách věnujících se imigraci se termíny „,izinec“, „imigrant“, „,̌adatel o azyl“ či „uprchlík“ propojují s důležitými politickými otázkami vnitřní bezpečnosti, kulturní a rasové př́íslušnosti a ekonomické prosperity státu. ${ }^{6}$ Je nesporné, že se imigrace tím, že je charakterizována jako jedna $\mathrm{z}$,nových“ bezpečnostních hrozeb, stala v celé řadě zemí předmětem procesu sekuritizace, a je tak stále více spojována se svým bezpečnostním rozměrem a potenciálem představovat ohrožení pro určitý referenční objekt. Imigranti jsou ve svých hostitelských zemích často spojováni se zvýšenou kriminalitou, společenskými nepokoji a národnostními spory. Přistěhovalci z muslimských zemí pak bývají zvláště po 11. září 2001 spojováni s hrozbou náboženského extremismu ${ }^{7}$ a pronikáním islamistických teroristických skupin do západních zemí. ${ }^{8}$ Tato tendence je patrná přibližně od poloviny 90 . let 20. století, kdy lze vysledovat významnou změnu oproti dřivějšímu stavu, nebot' v 60. a 70. letech 20 . století bylo na migraci pohlíženo jako na fenomén spojený spíše se socioekonomickými a ekologickými procesy. ${ }^{9}$

Souvislosti mezi migrací a ohrožením bezpečnosti se lze věnovat hned ve třech dimenzích - ohrožení migrantů během jejich putování; ohrožení bezpečnosti v zemi původu imigrantů, které je důvodem pro emigraci; a v neposlední řadě může migrace znamenat hrozbu pro cílový stát imigrantů a společnost v něm žijícíi ${ }^{10}$ Právě poslední případ, tedy imigrace (z Iráku) znamenající potenciální hrozbu pro cílovou zemi (Českou republiku), je předmětem této práce. 
Další možnost, jak na propojení migrace a záležitostí bezpečnosti pohlížet, představuje Anioł, který rozlišuje tři roviny, kdy může být mezinárodní migrace spojována s ohrožením bezpečnosti:

a) Migrace může být důsledkem jiné bezpečnostní hrozby - porušování lidských práv, etnických konfliktů, vnitrostátních konfliktů.

b) Dále může migrace představovat hrozbu pro vnitřní bezpečnost, pokud je masivní a nekontrolovatelná.

c) Migrace může mít za následek další ohrožení bezpečnosti (např. xenofobii a rasovou nesnášenlivost). ${ }^{11}$

Stejně tak může být spojení migrace a bezpečnostních otázek rozlišeno dle složek bezpečnosti, které jí mohou být ohroženy. Lze tedy rozlišit, které hodnoty, chráněné jako referenční objekt, mohou být mezinárodní migrací a jejími následky ohroženy.

a) Pokud je imigrace doprovázena nárůstem xenofobie a nedostatečnou integrací, může být ohrožena společenská stabilita.

b) Mezinárodní migrace může změnit, ohrozit demografické složení obyvatelstva (vysoká emigrace mladších lidí může prohloubit problémy spojené s procesem stárnutí populace).

c) Mezinárodní migrace může představovat hrozbu pro kulturní identitu společenství.

d) Imigrace může ohrozit stabilitu sociálního zabezpečení v daném společenství (lidé mohou ztratit ochotu přispívat do sociálního zabezpečení prostřednictvím daní při konfrontaci $\mathrm{s}$ př́ípadnou nízkou ekonomickou aktivitou imigrantů).

e) Migrace může představovat hrozbu pro vnitřní bezpečnost, což může být ilustrováno kriminalitou imigrantů, mezinárodními kriminálními sítěmi (např. pašování drog či zbraní), pašováním lidí, terorismem.

f) Hrozbu pro hostitelský stát mohou představovat i dobře organizované diaspory, které se mohou případně těšit z podpory svých domovských států. Eventuálně hrozí přenesení konfliktu z domovské země emigrantů do země cílové. ${ }^{12}$

\section{IMIGRANTI A IRÁČANÉ V ČESKÉ REPUBLICE}

\section{Česká republika jako nový domov pro cizince}

Mezi lety 1948 a 1989 mělo Československo ve srovnání s dneškem velice málo imigrantů. Komunistický režim uplatňoval přísnou migrační politiku a pohyb přes státní hranice oběma směry byl silně omezován, přesto byla přítomna významná nelegální emigrace československých občanů. Migrační toky do Československa byly specifické a zahrnovaly zpravidla pouze občany ostatních socialistických a „spřátelených“ zemí. Ti sem přijížděli hlavně v 70. a 80 . letech 20 . století na základě mezivládních smluv v rámci ,internacionální pomoci“. Počty cizinců trvale usazených v Československu byly nízké, v 80. letech 20. století jich zde žilo celkem 28000 s povoleným trvalým pobytem a $9000 \mathrm{~s}$ pobytem dlouhodobým. K významnému zvratu došlo po listopadu 1989, kdy se v souvislosti se všemi změnami stalo Československo, respektive Česká republika, významnou zemí tranzitní a v mnoha případech i cílovou. Až do roku 1997 zde byla bez zkušeností se zvládáním velkých imigračních toků a s integrací imigrantů aplikována velmi liberální migrační politika a praxe. Poloha země ve středu Evropy znamenala př́liv mnoha tranzitních migrantů, kteří se snažili přes ČR dostat dále na západ. Př́íliv imigrantů nebyl omezen ani hospodářskými problémy z konce 90 . let minulého století, ani změnou legislativy, která se, hlavně v souvislosti se vstupem do Evropské unie, stala systematičtější, selektivnější a restriktivnějšši. ${ }^{13}$

Česká republika představuje stále zemi, která je pro část cizinců spíše zemí tranzitní než cílovou, což platí zpravidla i o osobách, které při vstupu do ČR požádají o mezinárodní ochranu. 
Ve skutečnosti se ovšem následně snaží dostat dále na západ a ochranu plynoucí z azylového řízení využívají k nelegální migraci do cílových zemí. ${ }^{14}$

Počet cizinců dlouhodobě žijících v ČR se až na výjimku z přelomu tisíciletí neustále zvyšuje. K 30. dubnu 2009 bylo v ČR registrováno 443870 cizinců majících povolení k pobytu. Přičemž nejpočetnějšími menšinami jsou Ukrajinci (133 548), Slováci (78 024) a Vietnamci (60 986). ${ }^{15}$

\section{Počet Iráčanů v České republice}

Oproti některým zemím západní Evropy poptávku po méně kvalifikovaných pracovních silách pokrývají v České republice Ukrajinci a další imigranti z východoevropských, případně balkánských zemí. Od 90. let minulého století pomalu stoupá imigrace z arabských zemí a každoročně přichází přibližně stovka přistěhovalců, což je číslo zaostávající daleko za údaji ze zemí západní Evropy. Příchod přistěhovalců z arabských zemí znesnadňuje rovněž přísná vízová politika České republiky vůči zemím Blízkého východu, např. ještě nedávno bylo pro získání víza nutné složení velké zálohy, což zkomplikovalo i vzájemné vztahy mezi Českou republikou a blízkovýchodními zeměmi. $^{16}$

Státních př́íslušníků Irácké republiky žilo v ČR k 30. dubnu 2009 celkem 364, přičemž 285 z nich má udělený trvalý pobyt. ${ }^{17}$ Od roku 1990 požádalo v České republice o mezinárodní ochranu 2197 Iráčanů, přičemž ve stejném období žádalo o mezinárodní ochranu v ČR celkem 87904 cizinců. Azyl byl od roku 1990 do konce roku 2008 udělen celkem 138 Iráčanům a doplňkovou ochranu, zavedenou v ČR v roce 2006 , jich získalo $57 .^{18} \mathrm{Z}$ těchto údajů vyplývá, že úspěšnost žadatelů z Iráku o mezinárodní ochranu v České republice je relativně malá, přesto patř́ Iráčané mezi desítku nejčetnějších státních příslušností azylantů v ČR ${ }^{19}$ Celkem bylo v ČR od roku 1990 do roku 2008 uděleno 3433 azylů (po roce 1993 jich bylo 2376) a 360 žadatelů dostalo doplňkovou ochranu. Podíl žadatelů, kteří v ČR dostanou azyl, je dlouhodobě spíše nízký a např. mezi léty 1993 až 2007 obdrželo azyl 2,7 \% žadatelů. Podíl mezi žadateli z Iráku je pak ve stejném období $4,4 \%{ }^{20}$

\section{Počet udělených azylů Iráčanům v České republice 1990-prosinec 2008}

\begin{tabular}{|c|c|c|}
\hline Rok & Státní prúslušnost Irák & Celkem uděleno azylů \\
\hline $\mathbf{1 9 9 0}$ & 1 & 30 \\
\hline $\mathbf{1 9 9 1}$ & 16 & 776 \\
\hline $\mathbf{1 9 9 2}$ & 18 & 251 \\
\hline $\mathbf{1 9 9 3}$ & 1 & 250 \\
\hline $\mathbf{1 9 9 4}$ & 2 & 116 \\
\hline $\mathbf{1 9 9 5}$ & 9 & 59 \\
\hline $\mathbf{1 9 9 6}$ & 9 & 162 \\
\hline $\mathbf{1 9 9 7}$ & 9 & 96 \\
\hline $\mathbf{1 9 9 8}$ & 6 & 78 \\
\hline $\mathbf{1 9 9 9}$ & 2 & 79 \\
\hline $\mathbf{2 0 0 0}$ & 7 & 133 \\
\hline $\mathbf{2 0 0 1}$ & 4 & 83 \\
\hline $\mathbf{2 0 0 2}$ & 8 & 103 \\
\hline $\mathbf{2 0 0 3}$ & 7 & 208 \\
\hline $\mathbf{2 0 0 4}$ & 4 & 142 \\
\hline $\mathbf{2 0 0 5}$ & 1 & 251 \\
\hline $\mathbf{2 0 0 6}$ & 7 & 268 \\
\hline $\mathbf{2 0 0 7}$ & 17 & 191 \\
\hline $\mathbf{2 0 0 8}$ & 10 & 157 \\
\hline Celkem & 138 & 3433 \\
\hline
\end{tabular}

Zdroj: Odbor azylové a imigrační politiky MV ČR. 
Od roku 2006 je rovněž udělována doplňková ochrana, která byla do konce roku 2008 udělena celkem 57 státním příslušníkům Irácké republiky. ${ }^{21}$

Následující graf přibližuje počet Iráčanů žijících od roku 1992 ke konci března roku 2009 na území ČR s trvalým či dlouhodobým pobytem (úspěšní žadatelé o azyl dostávají automaticky i trvalý pobyt). Zatímco do roku 1997 převažoval počet Iráčanů s dlouhodobým pobytem, od roku 2000 se ukazuje jasný vzestup počtu Iráčanů s pobytem trvalým, stejně tak jako je zřejmý nárůst celkového počtu Iráčanů v České republice. Právě nárůst počtu Iráčanů s trvalým pobytem na úkor Iráčanů s dlouhodobým pobytem svědčí o neochotě Iráčanů k návratu do své vlasti, a imigraci z Iráku lze proto charakterizovat jako imigraci nezvratnou.

Občané Iráku s povoleným pobytem na území ČR v letech 1992-2009

\section{Občané Iráku s povoleným pobytem na území ČR v letech 1992-2009 - podle druhu pobytu}

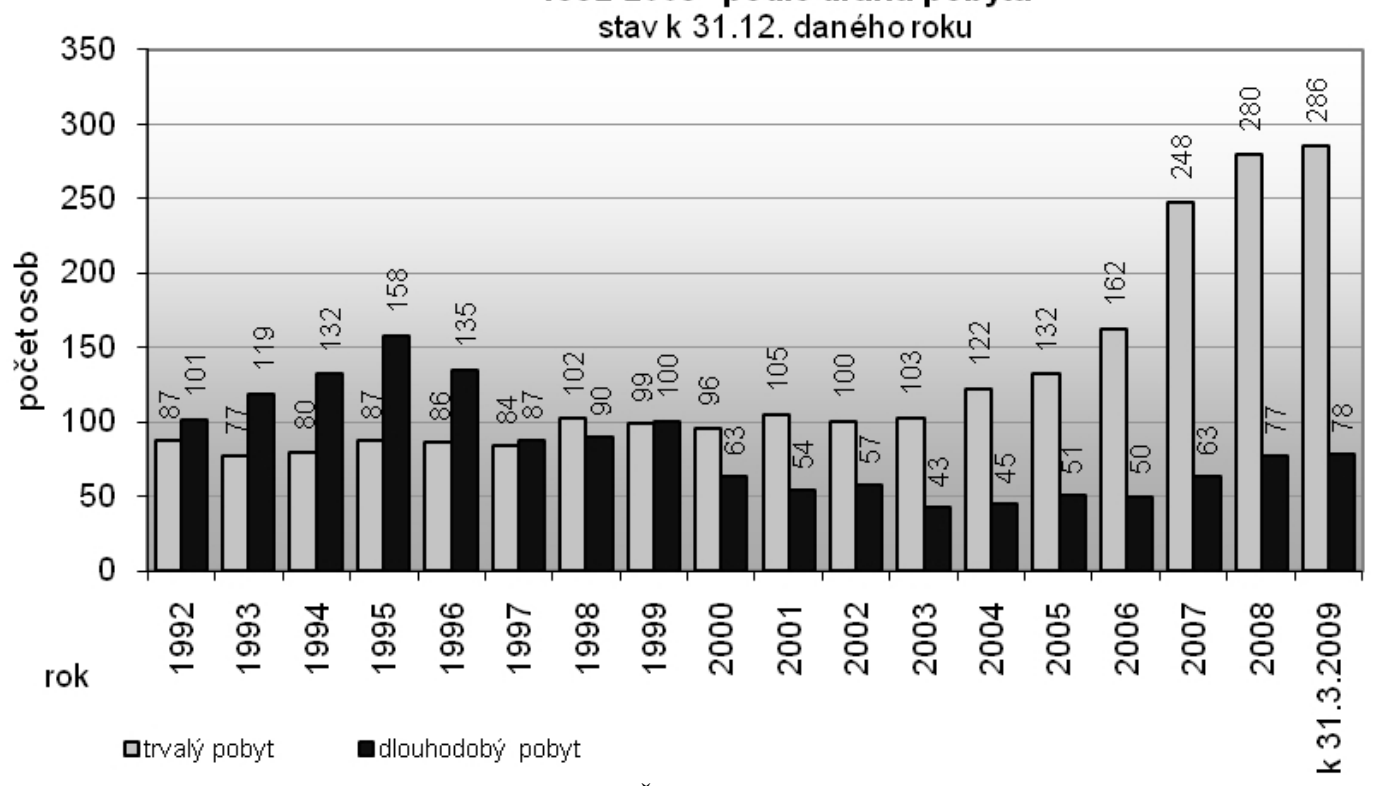

Zdroj: Odbor azylové a migrační politiky MV ČR.

Sečteme-li počet úspěšných žadatelů o azyl (a doplňkovou ochranu) ${ }^{22}$ a počet Iráčanů, kteří mají v současné době pobyt trvalý (bez držitelů azylu) či dlouhodobý, s počtem Iráčanů, kterým bylo uděleno občanství České republiky (od roku 1993 do roku 2008 jich bylo celkem 118), lze odhadnout počet osob majících svůj původ na území Iráku na asi 500 až 600 . Přičemž je v tomto odhadu počítáno i s Iráčany, kteří získali české, respektive československé občanství již před rokem 1993, jejich přesný počet však není k dispozici. 
Udělená státní občanství ČR státním příslušníkům Irácké republiky

\begin{tabular}{|l|c|c|}
\hline \multirow{2}{*}{ Rok } & \multicolumn{2}{|c|}{ Počet } \\
\cline { 2 - 3 } & Celkem & Z toho azylantů \\
\hline $\mathbf{1 9 9 3}$ & 12 & - \\
\hline $\mathbf{1 9 9 4}$ & 3 & - \\
\hline $\mathbf{1 9 9 5}$ & 12 & - \\
\hline $\mathbf{1 9 9 7}$ & 11 & - \\
\hline $\mathbf{1 9 9 8}$ & 10 & - \\
\hline $\mathbf{1 9 9 9}$ & 10 & - \\
\hline $\mathbf{2 0 0 0}$ & 5 & - \\
\hline $\mathbf{2 0 0 1}$ & 10 & - \\
\hline $\mathbf{2 0 0 2}$ & 2 & - \\
\hline $\mathbf{2 0 0 3}$ & 8 & 1 \\
\hline $\mathbf{2 0 0 4}$ & 7 & 1 \\
\hline $\mathbf{2 0 0 5}$ & 5 & 1 \\
\hline $\mathbf{2 0 0 6}$ & 8 & 1 \\
\hline $\mathbf{2 0 0 7}$ & 5 & 5 \\
\hline $\mathbf{2 0 0 8}$ & 6 & Není k dispozici \\
\hline Celkem & 418 & 9 \\
\hline$Z 20 j$ & 6 & \\
\hline
\end{tabular}

Zdroj: Odbor všeobecné správy MV ČR, oddělení státního občanství a matrik; Český statistický úřad.

Iráčané ovšem v České republice pravděpodobně žijí i ilegálně. Významnou část nelegálních imigrantů tvoří cizinci, kteří přišli do země legálně na základě udělených víz a následně překročili dobu oprávněného pobytu. ${ }^{23} \mathrm{Za}$ nelegální migraci lze ale rovněž považovat nelegální vstup na území státu či jeho opuštění (po vstupu do schengenského prostoru jsou jediným místem vnější schengenské hranice v ČR vybraná mezinárodní letiště). Dle údajů z odboru azylové a migrační politiky Ministerstva vnitra bylo v roce 2008 zaznamenáno 29 Iráčanů, kteří porušili podmínky pobytu v České republice (celkem bylo takto zjištěno 3661 cizinců) a 14 Iráčanů bylo registrováno při porušení podmínek vstupu do země (celkem se to týkalo 168 cizinců). Vrchol v počtu Iráčanů zachycených na státních hranicích znamenal rok 1997, kdy jich bylo zadrženo 2 326. Dále docházelo k poklesu počtu takto zadržených, ovšem v roce 2006 byl zaznamenán opětovný nárůst jejich počtu (z 35 z let 2004 a 2005 na 112), což zřejmě souvisí se zhoršením situace v Iráku. Tato čísla již ovšem nelze srovnávat s údaji z 90. let 20. století. 


\section{Nelegální migrace občanů Iráku přes státní hranice České republiky v letech} 1993-2007

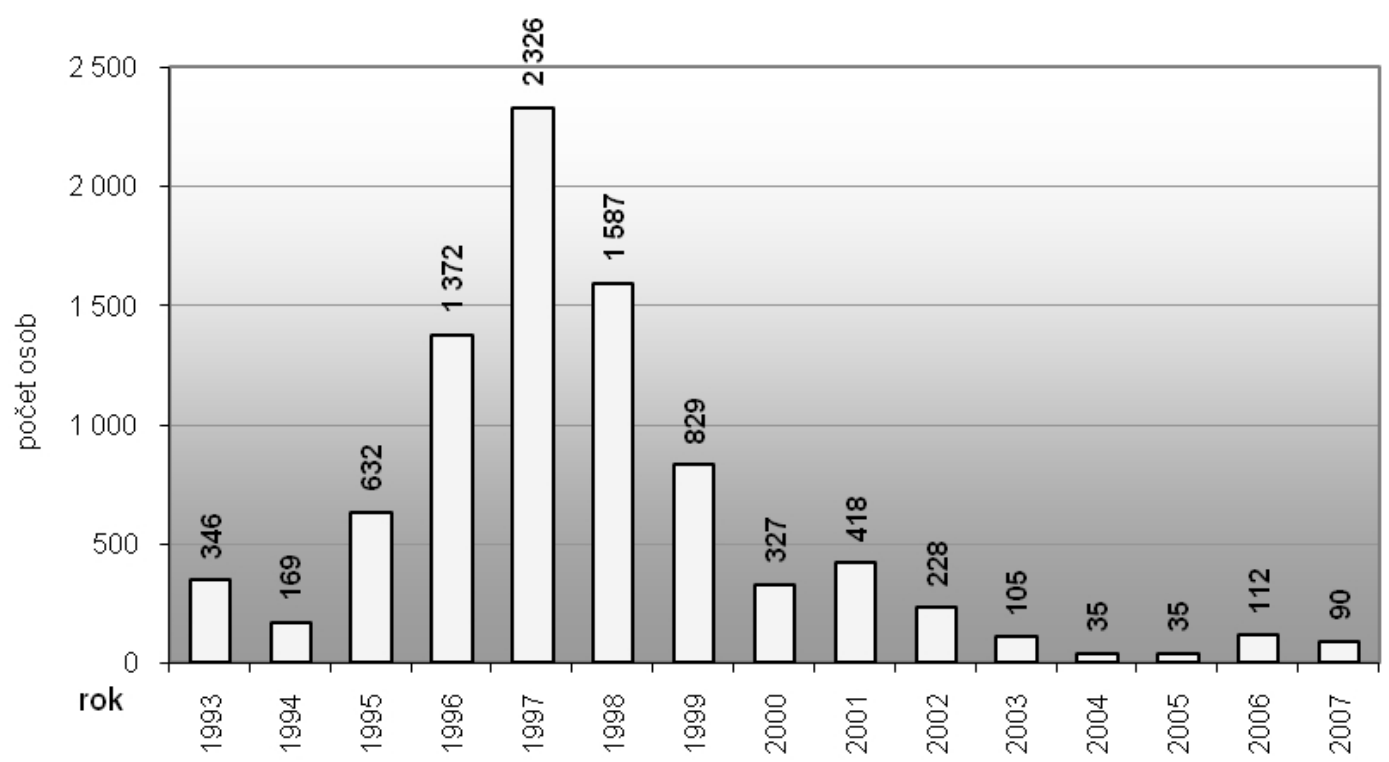

Zdroj: Odbor azylové a migrační politiky MV ČR.

Nelegální migrace občanů Iráku - neoprávněný pobyt v letech 1999-2007*

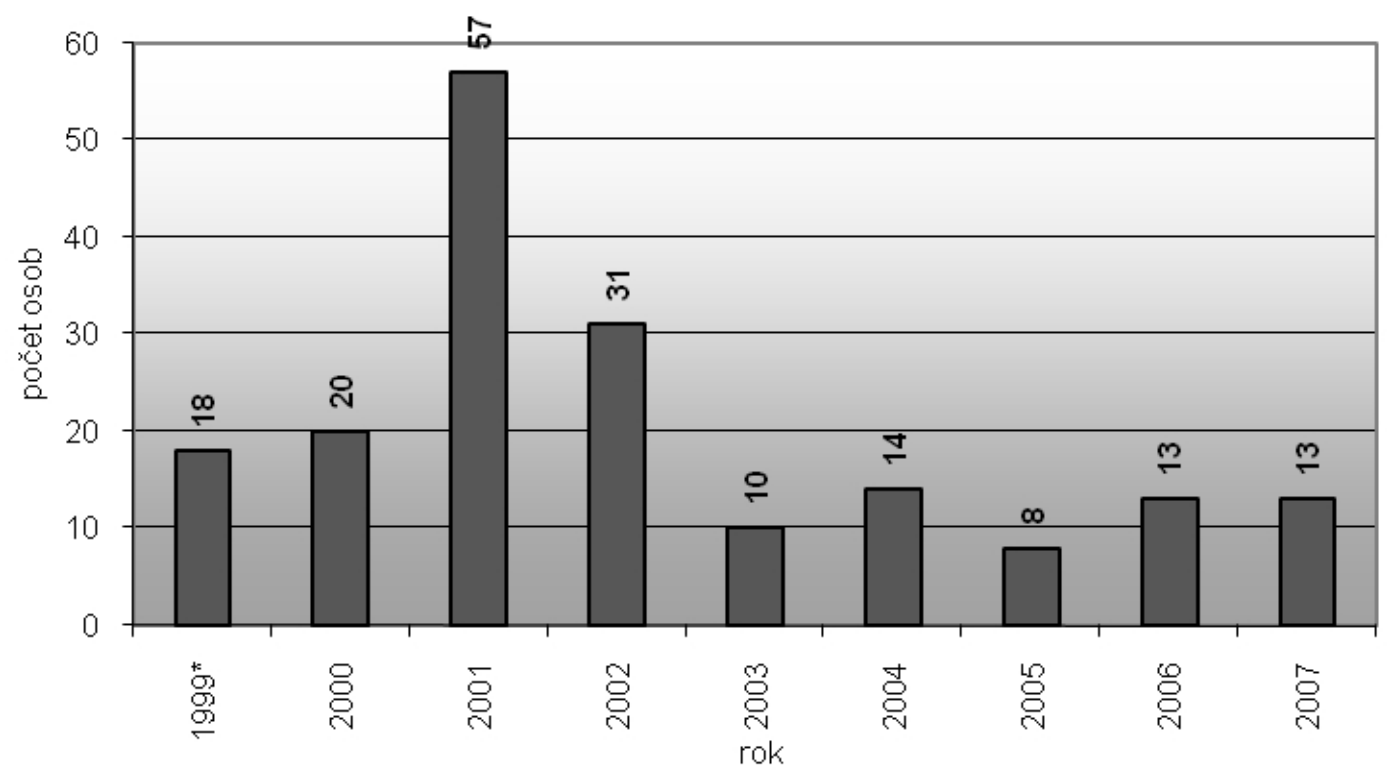

*Kategorie cizinců v nelegální situaci je vykazována od 1. 6. 1999.

Zdroj: Odbor azylové a migrační politiky MV ČR. 


\section{IRÁČANÉ ŽIJÍCÍ V ČESKÉ REPUBLICE A JEJICH INTEGRACE DO ČESKÉ SPOLEČNOSTI}

Významnou část osob původem z Iráku žijících nyní v České republice tvoří původně studenti, kteří přišli do tehdejšího Československa studovat a ačkoli se měli po dokončení svých studií vrátit, z různých důvodů zde zůstali. ${ }^{24}$ Těchto studentů bylo dle údajů Domu zahraničních služeb celkem asi 450 , přičemž většinu tvořili stipendisté Komunistické strany Iráku. ${ }^{25} \mathrm{~K}$ tomuto údaji je ovšem nutné přičíst i posluchače mimo civilní školy, kteří se vzdělávali např. na Vojenské akademii Antonína Zápotockého v Brně či na jiné vojenské škole v Československu. V polovině 80. let minulého století jich jen na brněnské akademii mohlo studovat najednou až $250{ }^{26} \mathrm{Je}$ ovšem velmi obtížné odhadnout počet Iráčanů, kteří se nevrátili zpět do své vlasti (či se po svém odcestování do Iráku opět vrátili do Československa, České republiky), a oficiální data nejsou k dispozici. Určitou představu o jejich počtu nám však mohou poskytnout informace z krajanských spolků. V Praze působí Irácké fórum, jehož členy jsou v naprosté většině právě dřívější studenti a které čítá dle vyjádření jeho představitelů přibližně 80 registrovaných členů (plátců členských příspěvků). Pravidelné akce pro Iráčany, které fórum pořádá, ovšem dle jejich vyjádření navštěvuje více než 200 Iráčanů (většinou z Prahy a širšího okolí), v drtivé většině vysokoškolsky vzdělaných lidí, kteří zde po svém studiu zůstali a založili rodiny. Další možnost k lepšímu odhadu podílu Iráčanů, kteří zde žijí již delší dobu, nám poskytuje statistika udělených trvalých pobytů (zvláště pak z počátku devadesátých let minulého století), kdy je pro udělení trvalého pobytu kromě jiného potřeba splnit podmínku pětiletého nepřetržitého pobytu. Rámcově tak lze počet Iráčanů, kteří v Československu studovali či pobývali již dříve a nyní žijí v České republice s českým občanstvím či dlouhodobým pobytem, odhadnout i na více než 300 .

Jak vyplývá z rozhovorů, které jsem s Iráčany vedl, většina dotázaných patř́ících mezi imigrační vlnu, která přišla do Československa před rokem 1989, si již nedokáže představit trvalý návrat do své původní vlasti. ${ }^{27}$ Partnerkami těchto Iráčanů jsou ve většině případů Češky a jejich děti se již takřka bez výjimky považují za Čechy a irácký původ jejich rodiče u nich vyvolává pouze zvýšený zájem o dění v Iráku. V komunitě Iráčanů žijících v České republice se však najdou i tací, kteří po dokončení svých studií odjeli zpět do Iráku a k opětovnému návratu (tentokrát již třeba i s rodinou) do České republiky je přiměla až bezpečnostní situace v Iráku po roce 2003, kdy se $\mathrm{z}$ nich $\mathrm{v}$ podstatě stali uprchlíci. V prŕípadě těchto imigrantů sehrála klíčovou roli právě již vytvořená vazba na Československo / Českou republiku - „studoval jsem tady, znám zákony a všechno ostatní“. ${ }^{28}$

Mezi Iráčany, kteří přršli do Československa studovat, však nebyli pouze členové či sympatizanti irácké komunistické strany. Spolu s nimi sem přišli i lidé podporující baasistický režim (v tomto př́ípadě spíše na vojenské školy a školy ministerstva vnitra) a stejně tak lidé apolitičtí i příslušníci různých menšin (Kurdové, Asyřané, křest'ané). Docházelo k poněkud paradoxní situaci, kdy Československo hostilo na svém území spolu s lidmi podporujícími baasistický režim (či ve straně prrímo angažovanými) i př́islušníky a sympatizanty opozičních sil - Kurdy a komunisty, se kterými vedla irácká vládní garnitura i otevřený boj. Ačkoli je i dnes složení členů komunity z hlediska politických názorů, jichž jsou nositeli, pestré, komplikace ve vzájemných vztazích mezi Iráčany kvůli jejich odlišnému politickému názoru dnes nejsou významnějšího rázu.

Lze říci, že Iráčané, kteří v Československu studovali, jsou již velmi dobře integrováni do většinové společnosti, ovládají jazyk a také díky svému vysokoškolskému vzdělání mají povětšinou vyšší sociální status. Někteří z nich mají české státní občanství, což do určité míry eliminuje jejich cizost a alespoň formálně $z$ nich činí občany rovné s většinovou společností. ${ }^{29} \mathrm{~J}_{\text {sou }}$ mezi nimi inženýři, architekti, podnikatelé, lékaři, ale i např. i vysokoškolský učitel atp. Iráčané, stejně jako členové české komunity muslimů, žijí převážně ve větších městech. Postoj Iráčanů (z různých imigračních vln) k České republice, který vyplynul z vedených rozhovorů, je velmi vřelý a považují ji za bezpečný domov. Až na výjimky nemají s Čechy a s životem v České republice 
negativní zkušenosti, výtky se zaměřují směrem ke složité byrokracii. ${ }^{30}$ Vztah Iráčanů, kteří žijí v České republice déle, k islámu lze označit za relativně vlažný a ani vztahy mezi Iráčany navzájem nejsou prŕliš ovlivněny jejich etnickým či náboženským původem. Respondenti bez výjimky hovořili o tom, že soužití mezi etnickými a náboženskými skupinami v Iráku probíhalo v podstatě bezproblémově a že byly běžné i sňatky a prátelství mezi členy různých skupin. Násilí v Iráku po roce 2003 je pro ně nepochopitelné a přisuzují je externím vlivům. Dva z respondentů dále poznamenali, že k nepatrnému posunu v rámci soužití komunity v ČR ovšem mohlo dojít po spojenecké invazi z roku 2003 a následném sektářském násilí v Iráku, kdy někteří Iráčané žijící v České republice (doposud nábožensky nepř́liš aktivní) začali např. poněkud „horlivěji“ slavit náboženské svátky charakteristické pro svůj proud v rámci islámu. Nyní by se ovšem situace měla vracet $\mathrm{k}$ původnímu stavu. ${ }^{31}$

\section{HROZBY SPOJENÉ S IMIGRACÍ Z IRÁKU DO ČESKÉ REPUBLIKY}

Jak již bylo předesláno $\mathrm{v}$ úvodní části této práce, jejím předmětem je posouzení rizik pramenících z imigrace Iráčanů do České republiky, která může pro Českou republiku a společnost v ní žijící představovat bezpečnostní hrozbu. Tato rizika je potřeba samozřejmě zvážit s ohledem na charakter Iráku, u kterého jde o národnostně heterogenní stát s jasnou dominancí jednoho náboženství - islámu (přičemž v Iráku tvoří většinu vyznavači jeho šíitské větve, zastoupena je i větev sunnitská), a charakter migrace odtud, poslední vývoj v Iráku a stejně tak dlouhodobější vzájemné vztahy s Českou republikou, respektive Československem.

Lze říci, že cizincům je často přičítán větší podíl na „běžné“ majetkové, prrípadně násilné a pouliční kriminalitě (roli ale hraje bezesporu i to, že kriminalita cizinců poutá daleko větší pozornost médií než totožná trestná činnost „domácích“ obyvatel). Zároveň existují další rizika v podobě např. poškozování ekonomických zájmů státu, resp. legálních výrobců a distributorů rozsáhlým paděláním a pašováním zboží, organizováním nelegálního trhu pracovních sil až po závažnější formy mezinárodní finanční kriminality, organizovaného zločinu a terorismu. ${ }^{32}$ Zvláštní úlohu u imigrace z muslimských zemí, mají obavy z islámského extremismu a terorismu, zejména po teroristických útocích na Spojené státy americké z 11. záŕí 2001 a několika následných útocích v Evropě. Z tohoto důvodu se pozornost odborníků, ale i médií a veřejnosti obrací směrem k muslimským komunitám. Irák je v mnohém specifický i v tom, že v zemi po spojenecké invazi z roku 2003 propuklo masivní násilí, z části i mezi místním obyvatelstvem, přičemž lze předpokládat, že zemi opouštěli či opouštějí Iráčané ze všech národnostních i náboženských skupin, které se vůči sobě na venek vymezují/vymezovaly nenávistně, a mezi emigranty mohou být jak pachatelé závažných trestných činů, tak představitelé režimu Saddáma Husajna.

Pokud budeme rozlišovat hodnoty, které jsou chráněny jako referenční objekt a mohou být imigrací z Iráku a jejími následky ohroženy, lze se soustředit na:

1. Možné ohrožení společenské stability z důvodu nedostatečné integrace imigrantů z Iráku a případného následného nárůstu xenofobie ve společnosti a ohrožení kulturní identity české společnosti,

2. Ohrožení stability sociálního zabezpečení v České republice,

3. Ohrožení vnitřní bezpečnosti České republiky kriminálními aktivitami Iráčanů,

4. Hrozbu terorismu,

5. Ohrožení bezpečnosti přenesením konfliktu mezi etnickými a náboženskými skupinami v Iráku imigranty do České republiky. Určitá rizika mohou pramenit z imigrace Iráčanů s vazbou na bývalý režim Saddáma Husajna. 


\section{IRÁČANÉ JAKO BEZPEČNOSTNÍ HROZBA PRO ČESKOU REPUBLIKU}

Jak je již uvedeno výše, imigrace z Iráku do České republiky může ohrozit určité hodnoty, referenční objekty. V této kapitole jsou jednotlivé možné hrozby představeny a ve vztahu k Iráčanům v České republice analyzovány.

\section{Ohrožení společenské stability $z$ důvodu nedostatečné integrace imigrantů $z$ Iráku a případného následného nárůstu xenofobie $v$ české společnosti a ohrožení kulturní identity české společnosti.}

Rostoucí kriminalita cizinců na území určitého státu společně s nezvládnutým imigračním tlakem může vést ke vzniku sociálních problémů, dezintegračním projevům ve společnosti, vzestupu xenofobních postojů většinové společnosti a následně politického extremismu a radikalismu u části většinové společnosti. ${ }^{33}$ Nedostatečná míra integrace do společnosti může ovšem zapříčinit i radikalizaci imigrantů samotných. Pro ty představuje stát s vyloučenými přistěhovaleckými komunitami takřka ideální podhoubí pro organizování radikálních a extremistických aktivit. $^{34}$

Jak je již předesláno výše, komunita Iráčanů v České republice je velice malá (500 až 600 osob) a její významnou část tvoří lidé, kteří jsou v České republice již delší dobu, ovládají jazyk, byli vzděláni na českých (či slovenských) vysokých školách, mají vyšší sociální status a jejich partnery jsou mnohdy Češi. „Nově“ příchozí Iráčané, kteří se přistěhovali po roce 1989 bez předchozích př́mých vazeb na Československo či Českou republiku, by mohli vzhledem ke svému malému počtu jen obtížně zvrátit charakter celé komunity. Důvodem může být i to, jak rovněž vyplývá z vedených rozhovorů, že část z těchto nověji prríchozích Iráčanů tvoří rodinní příslušníci Iráčanů žijících zde již delší dobu.

Doposud se komunita Iráčanů nestala cílem nějakého významnějšího cíleného útoku. Pozornost občas upoutá česká muslimská komunita, do které lze, i přes určité výjimky, Iráčany rovněž začlenit. Počet muslimů v České republice je odhadován na 11000 až 20000 . $^{35}$ Lze zaznamenat občasné aktivity (např. výlep plakátů či pomalování zdí brněnské mešity) namířené proti islámu. Na internetu je možno najít některé protiislámsky zaměřené české stránky a stejně tak proti muslimům vystupuje marginální Národní strana. Další radikální strana - Dělnická strana sama reflektuje, že „nebezpečí“ islámu není u nás oproti Evropě prozatím aktuální, a její pozornost se soustředí spíše na problematiku soužití s Romy. ${ }^{36}$ Tyto jevy ovšem nemají významnější podporu veřejnosti a čeští muslimové vůči nim vystupují smírlivě. Diskuse s tematikou islámu se objevuje i v českých médiích, přičemž občas bývá automaticky propojována muslimská víra s terorismem. Představitelé muslimské komunity ovšem hodnotí takovéto informace jako zkreslené a namírené proti islámu, přičemž jejich odpor je poklidný. ${ }^{37}$ Zároveň nelze konstatovat, že by zvláštní pozornost české společnosti poutala právě komunita Iráčanů a nelze ani v současné době předpokládat, že by nedostatečná integrace Iráčanů do české společnosti mohla mít za následek radikalizaci této komunity či ohrožení kulturní identity Čechů.

\section{Ohrožení stability sociálního zabezpečení v České republice}

Společnosti cílových zemí imigrantů musí čelit otázce nespravedlivého prrístupu, kdy jsou legální pracovníci v mnoha ohledech $\mathrm{v}$ nevýhodném postavení vůči pracovníkủm nelegálním (nelegální pracovníci mohou dostávat nižší mzdu či pracovat v horších podmínkách). Stejně tak mohou být díky nižším nákladům v konkurenční výhodě firmy, které nelegální pracovníky zaměstnávají. Dále se k tomuto problému připojuje problém cenového dumpingu, kdy vyplácením menších odměn nelegálním imigrantům (oproti legálním zaměstnancům) dochází k podkopávání stability nastavených pravidel. Dalšími negativy mohou být ztráty na daních a sociálním a zdravotním pojištění, vznikající nenahlášením daných nelegálních pracovníků a tím i neodváděním 
těchto odvodů. Negativně se může imigrace projevovat zvýšením výdajů státu na vzdělávání dětí a mládeže imigrantů. ${ }^{38}$

Rizikem může být rovněž vzestup nevole obyvatel platit daně a další odvody, pokud jsou konfrontováni s tím, že jiná skupina obyvatel tyto povinnosti neplní ani př́ípadně nesdílí stejné hodnoty. To by mohl být prŕklad ekonomicky neaktivních imigrantů a žadatelů o azyl, kteří využívají výhod sociálního systému. ${ }^{39}$

V české společnosti se tendence kritizovat nadužívání sociálního systému menšinami objevují, přičemž lze pozorovat, že se na tomto tématu profilují i někteří politici patřící i do významnějších stran a těšící se ne nevýznamné podpoře veřejnosti. V této souvislosti se hovoří hlavně o romské menšině, ovšem určitou pozornost poutají i imigranti, kteří ale nevyvolávají větší kontroverze. $\mathrm{V}$ případě Iráčanů usazených na území České republiky však nelze hovořit o významnějším vlivu na ohrožení sociální stability České republiky, a to z důvodů uvedených výše. Irácká komunita je velmi malá a její charakter ji oproti jiným přistěhovaleckým komunitám poněkud zvýhodňuje (pouze část Iráčanů přišla do České republiky po roce 1989, zároveň jde o komunitu vzdělanou a integrovanou do české společnosti). Část Iráčanů dokonce v České republice podniká, což přináší další možnosti pracovního uplatnění také pro většinové obyvatelstvo.

\section{Ohrožení vnitřní bezpečnosti České republiky kriminálními aktivitami Iráčanů}

Kriminalita bývá velmi často společností přistěhovaleckých států vnímána jako nejvýznamnější negativum spojené s imigrací, přičemž výjimkou nejsou ani obyvatelé České republiky. Jak vyplynulo i z nedávného výzkumu Centra pro výzkum veřejného mínění Akademie věd ČR, celých $74 \%$ Čechů souhlasí s tvrzením, že se cizinci podílejí na nárůstu kriminality. ${ }^{40}$

V roce 2008 u nás bylo trestně stíháno celkem 9720 cizinců, což znamená malý nárůst oproti předchozímu roku. Na počtu trestně stíhaných cizinců za rok 2008 se do jisté míry odráží situace v oblasti legální i nelegální migrace na území České republiky. Hodnota podílu cizinců na počtu trestně stíhaných osob má od roku 2002 mírnou, nicméně nepřetržitě stoupající tendenci (z $5 \%$ na $7 \%$ v roce 2008). To souvisí zejména s faktem trvalého nárůstu počtu cizinců žijících formou povoleného pobytu na území ČR. Nejvíce trestně stíhaných občanů bylo ze Slovenské republiky (3 663), Ukrajiny (1 601), Vietnamu (901) a Polska (482). ${ }^{41}$

Občanů Irácké republiky bylo v roce 2008 trestně stíháno celkem 6 (v roce 2007 jich bylo 7) a objasněno bylo 7 trestných činů spáchaných Iráčany (v roce 2007 jich bylo vysvětleno13). Od roku 1994 byl nejvyšší počet Iráčanů vyšetřovaných pro trestnou činnost v jednom roce 15 (2001) a nejnižší 3 (1994 a 2003). Následující tabulka nám může poskytnout přehled o charakteru trestných činů páchaných v České republice Iráčany v letech 2007 a 2008.

\section{Objasněné trestné činy státních př́íslušníků Irácké republiky na území ČR v roce 2007 dle jednotlivých druhů}

\begin{tabular}{|l|c|}
\hline Název & Počet trestných činů \\
\hline Úmyslné ublížení na zdraví & 1 \\
\hline Nebezpečné vyhrožování & 1 \\
\hline Nedovolené překročení státní hranice & 2 \\
\hline Nedovolená výroba a držení psychotropních látek a jedů & 2 \\
\hline Zločinné spolčení & 1 \\
\hline Ostatní trestná činnost & 1 \\
\hline Krácení daně & 1 \\
\hline
\end{tabular}




\begin{tabular}{|l|c|}
\hline Padělání a pozměňování veřejné listiny & 2 \\
\hline Podvod & 1 \\
\hline Neoprávněné držení platební karty & 1 \\
\hline Celkový součet & $\mathbf{1 3}$ \\
\hline
\end{tabular}

Zdroj: Odbor bezpečnostní politiky MVČR; PP PČR.

\section{Objasněné trestné činy státních příslušníků Irácké republiky na území ČR v roce 2008 dle jednotlivých druhů kriminality}

\begin{tabular}{|l|c|}
\hline Název & Počet trestných činů \\
\hline Poškozování cizí věci & 1 \\
\hline Výtržnictví & 1 \\
\hline Nedovolené překročení státní hranice & 1 \\
\hline Zanedbání povinné výživy & 1 \\
\hline Podvody proti sociálnímu zabezpečení a nemocenskému pojištění & 1 \\
\hline Padělání a pozměňování veřejné listiny & $\mathbf{7}$ \\
\hline Celkový součet & \\
\hline
\end{tabular}

Zdroj: Odbor bezpečnostní politiky MVČR; PP PČR.

Z tabulek vyplývá, že počet odhalených trestných činů páchaných Iráčany v České republice je relativně malý a že se jedná spíše o méně závažnou trestnou činnost (z těch četnějších např. padělání a pozměňování veřejné listiny, zanedbání povinné výživy). Nejzávažnějším odhaleným trestným činem, kterého se v roce 2007 a 2008 dopustil státní př́íslušník Iráku na území České republiky, byla účast na zločinném spolčení. ${ }^{42}$ Ve zbývajících případech jde o méně závažnou trestnou činnost s nižší společenskou nebezpečností.

V případě zločinného spolčení z roku 2007 šlo o členství Iráčana ve skupině organizátorů nelegální migrace (zadržené v květnu roku 2007 z podnětu Bezpečnostní informační služby) z oblasti severní Afriky, Blízkého východu a Iráku. Skupina se původně soustředila hlavně na Egypt’any, poté, co pro ně byla zavedena tranzitní víza, přešla jejich pozornost na Iráčany. Využívali toho, že linka z Káhiry do Moskvy má mezipřistání v Praze, kde požádali emigranti o azyl. Následně utekli z uprchlického tábora a skupina, v jejímž čele stál Libanonec, pak organizovala jejich cestu dále na západ. ${ }^{43}$ Podíl Iráčanů na nelegální imigraci je ovšem v českém kontextu záležitostí spíše několika málo jednotlivců. ${ }^{44}$ Iráčané jsou tak spíše v rolích obětí skupin převaděčů.

Celkově se cizinci na organizovaném zločinu v České republice podílejí přibližně polovinou, Iráčané však patří mezi ojediněle se vyskytující národnosti. Z arabských zemí je takováto kriminalita doménou spíše Alžířanů či Tunisanů apod. ${ }^{45}$

Z vyjádření detektiva Útvaru pro odhalování organizovaného zločinu Policie ČR (ÚOOZ), pplk. Ratajského, vyplývá, že se Iráčané v zásadě nepodílejí na zjevné trestné činnosti, ale případně spíše na latentní hospodářské kriminalitě. Drobná kriminalita není pro Iráčany charakteristická. Podle něj má ÚOOZ s Iráčany jakožto pachateli pouze minimální zkušenosti. Iráčané, kteří zde žijí delší dobu, se na této činnosti bud' nepodílejí, anebo je tato činnost velmi sofistikovaná a nenápadná. Existuje tedy podezření, že se někteří Iráčané účastní latentní hospodářské kriminality s vysokými zisky, kdy spolupracují se zločinci dalších národností. Spíše však jde o jednotlivce, a to 
hlavně mezi nověji příchozími imigranty. V této souvislosti jeden respondent hovořil o pozoruhodně vysokém počtu směnáren v centru Brna, které vlastní Iráčané. ${ }^{46}$ Počet nových imigrantů z Iráku, kteří mají povolený pobyt, je však velmi malý a tuto kriminální činnost nelze označit za větší riziko pro stát než organizovaný zločin český, případně vietnamský. Lze se ovšem domnívat, že právě hospodářská kriminalita Iráčanů je ze strany této komunity tou nejzávažnější hrozbou. ${ }^{47}$

\section{Terorismus}

Terorismus představuje jednu ze zásadních bezpečnostních výzev pro celý svět a Česká republika není výjimkou. Pozornost se na něj začala soustřed'ovat zvláště po 11. září 2001, přičemž i české bezpečnostní složky považují za nejrizikovější islámský extremismus a terorismus. V Evropě jsou vhodným prostředím pro islámské radikály tamější muslimské komunity. Ta česká doposud na různé události a provokace v ČR i ve světě reaguje smírně. O riziku teroristického útoku na Českou republiku se hovoří zvláště ve spojitosti s naším členstvím v Severoatlantické alianci, angažovaností armády v zahraničních misích a vysíláním rádia RFE/RL. ${ }^{48}$

Aktivity teroristických organizací v ČR nebyly doposud zaznamenány. Byly prověřovány signály o přítomnosti jednotlivých členů teroristických skupin na našem území, ale nebyla potvrzena snaha těchto osob o zneužití ČR k přípravě nebo realizaci teroristické akce. Byla provedena opatření vůči členům Hizballáhu, prověrka možnosti pobytu osob spojených s egyptským a afghánským terorismem $\mathrm{v}$ ČR, opatření $\mathrm{k}$ prověření možnosti výskytu aktivit al-Káidy v ČR. ${ }^{49}$

Zřejmě největším rizikem pro Českou republiku z pohledu terorismu je právě její tranzitní role v mezinárodní migraci - může tak dojít ke krátkodobému výskytu osob podezřelých z napojení na různé teroristické skupiny. ${ }^{50}$

Jednou z charakteristik nelegálních imigrantů původem z Iráku je, že nemají žádný doklad totožnosti, eventuálně se prokazují padělanými cestovními doklady nebo doklady jiných členských států Evropské unie. Právě tato snaha o zakrytí své identity může podle poznatků Bezpečnostní informační služby indikovat možné bezpečnostní riziko pro ČR, plynoucí z nemožnosti odhalit případné prříslušníky radikálních či militantních, islámem inspirovaných skupin (poprrípadě osoby s vazbou na bývalý irácký režim). ${ }^{51}$

Vzhledem k již výše uvedené povaze komunity Iráčanů žijících v České republice, která má oproti jejich pospolitostem $\mathrm{v}$ jiných evropských státech $\mathrm{v}$ mnohém specifický charakter, nelze říci, že by Iráčané v současnosti představovali pro ČR z hlediska aktivit spojovaných s islámským extremismem a terorismem významnější riziko. Určité riziko představují imigranti, kteří přišli v poslední době a zvláště pak ilegální imigranti či lidé, kteří se do ČR dostanou přes vnitřní hranici Evropské unie. Ti mohou být i ovlivněni situací v Iráku posledních let.

Lze se domnívat, že riziko teroristického útoku ze strany Iráčanů je možná nižší, než jak tomu bylo před rokem 2003, kdy panovaly určité obavy z teroristické akce Iráku vưči RFE/RL. ${ }^{52}$

Iráčané, kteří jsou v České republice delší dobu, mají malý zájem na tom, aby byli spojováni jak se závažnou trestnou činností, tak s náboženským extremismem, což by mohlo uškodit jejich případnému podnikání či klidnému životu v České republice. Větší riziko představují spíše Alžírané, Jemenci či Egypt'ané. ${ }^{53}$

\section{Hrozba přenesení konfliktu mezi etnickými a náboženskými skupinami v Iráku prostřrednictvím imigrantů do České republiky. Rizika plynoucí z imigrace Iráčanů s vazbou na bývalý režim Saddáma Husajna.}

Vzhledem k nízkému počtu imigrantů v Iráku nelze očekávat i přes možný příchod přistěhovalců, u kterých je obtížné či nemožné zjistit jejich skutečnou identitu, že by mohlo dojít k přenesení násilí z Iráku do ČR. Masivní vlna násilí, která v Iráku nastala po roce 2003, poukázala 
mimo jiné na fakt, že irácká společnost je značně heterogenní. Složení irácké komunity v ČR v podstatě reflektuje strukturu obyvatelstva v Iráku. Tvoří ji jak zástupci šíitů, sunnitů a Kurdů, tak Asyřané či křest’ané. Stejně tak lze komunitu rozdělit na nově příchozí Iráčany a ty, kteří jsou v ČR již delší dobu, a zároveň dochází k dělení ve vztahu k bývalému iráckému režimu.

Lze říci, že vztahy mezi Iráčany navzájem nejsou prŕliš ovlivněny jejich etnickým či náboženským původem. Respondenti bez výjimky hovořili o tom, že soužití mezi etnickými a náboženskými skupinami v Iráku probíhalo v podstatě bezproblémově a že byly běžné i blízké vztahy mezi jednotlivými skupinami. Někteři respondenti ostatně vyjadřují přesvědčení, že poslední vlna násilí nemá příliš společného s rozpory mezi etnickými a náboženskými skupinami v Iráku, ale že je spíše způsobena vnějšími vlivy. K určité změně ve vzájemných vztazích v české komunitě ovšem mohlo dojít po spojenecké invazi z roku 2003 a následné vlně násilí v Iráku, kdy mohlo nastat krátkodobé zvýšení napětí v rámci komunity. Nová imigrační vlna je natolik malá, že neměla vliv na soužití komunity Iráčanů. ${ }^{54}$ Zároveň lze říci, že nově příchozí nejsou s ostatními Iráčany v ČR v př́liliš úzkém kontaktu. ${ }^{55}$

Úzké vztahy Československa s baasistickým režimem a zároveň s iráckou komunistickou stranou měly za následek, že na straně jedné se Praha stala významným centrem opozice vůči iráckému režimu a jezdili sem stipendisté Komunistické strany Iráku, a na straně druhé se do Československa jezdili vzdělávat vojáci či policisté, tedy osoby (vzhledem k charakteru iráckého režimu) se stranou Baas spjaté. $Z$ tohoto důvodu dnes najdeme v České republice Iráčany jak $\mathrm{s}$ režimem $\mathrm{v}$ různé míre spojené (či ho alespoň dříve podporující), tak osoby stavějící se v podstatě od jeho počátku do opozice. Nelze však říci, že by dnes tato skutečnost vyvolávala mezi Iráčany významnější kontroverze. Projevuje se spíše v osobní rovině např. tím, že se mezi sebou příliš nestýkají (kupříkladu kvůli tomu, že pražské Irácké fórum působí levicověji). ${ }^{56}$

\section{ZÁVĚR}

Irák patří mezi země, které jsou významným způsobem ovlivněny vystěhovalectvím, přičemž výrazný byl i tzv. odliv mozků, kdy velká část inteligence odešla či byla donucena odejít do zahraničí, a to v celém období existence Irácké republiky po roce 1958. Iráčané odcházeli do okolních zemí, ale hledali útočiště či příležitosti k uplatnění, př́ípadně vzdělání i např̀. v Československu / České republice.

Migrace, zvláště pak pokud je skutečně masivní a nekontrolovaná, může představovat pro stát, který imigranty přijímá, významnou bezpečnostní hrozbu. $Z$ tohoto důvodu se migrace stává čím dál tím častěji tématem výzkumu nejenom sociologie, ale i bezpečnostních a strategických studií a zároveň dochází $\mathrm{k}$ její sekuritizaci, a to jak na úrovni národní, tak na úrovni nadnárodní. V této souvislosti má ČR v mnohém poněkud odlišnou pozici oproti „etablovanějším“ imigrantským zemím. Po dlouhou dobu byla imigraci až na drobné výjimky uzavřena a ani nyní nepatří, i přes ustavičný nárůst počtu cizinců zde žijících, pro emigranty z oblasti Blízkého východu mezi nejatraktivnější cíle, spíše je pro ně stále zemí tranzitní.

Komunita Iráčanů, respektive i komunita muslimů zde žijících, je rovněž v mnohém, oproti obdobným komunitám v „tradičních“ přistěhovaleckých zemích, specifická. V obou případech (prozatím) jde o komunitu malou a do značné míry takřka bezproblémově integrovanou do české společnosti, která nepoutá větší pozornost. Zvláště pak irácká komunita (respektive komunita v Iráku narozených lidí), jejíž velikost lze odhadnout na 500 až 600 osob, je zajímavá ve své struktuře. Většinou ji tvoří Iráčané, kteří žijí v České republice již delší dobu, studovali zde, velmi často mají za partnery Čechy, relativně úspěšně zde žijí a pracují a jejich vztah k ČR je pozitivní. Tuto komunitu lze v podstatě rozdělit na dvě části - na Iráčany, kteří zde žili či studovali díky nadstandardním a dlouhodobým vztahům mezi Československem a Irákem již před rokem 1989 (jejich počet můžeme odhadnout na asi 300 osob), a na Iráčany, kteří přišli do České republiky po „sametové revoluci“. Imigraci (minimálně první části) Iráčanů lze označit za trvalou, nebot' 
povětšinou neplánují návrat do Iráku, imigrace po roce 1989, zvláště pak od konce 90. let 20. století, však může mít i charakter imigrace cyklické.

Určité riziko mohou představovat lidé, kteří přišli v pozdější imigrační vlně, kdy se do ČR mohli dostat Iráčané s nejasnou minulostí a bez jakýchkoliv vazeb na ČR. Zatím jich však, i díky př́ísné imigrační politice, která je u nás praktikována, není mnoho.

I z těchto důvodů tak lze dojít k závěru, že z mnou vybraných možných bezpečnostních hrozeb, které mohou být dávány do souvislosti s imigrací z Iráku, je do určité míry relevantní zejména ohrožení vnitřní bezpečnosti ČR kriminálními aktivitami Iráčanů. Třebaže i v tomto případě lze hovořit pouze spíše o jednotlivcích, kteří tuto trestnou činnost páchají. Nejvíce diskutovaná hrozba v souvislosti s muslimskými komunitami v současné Evropě, hrozba terorismu ze strany vlastní přistěhovalecké muslimské komunity (ale i třeba konvertitů), není pro tuto chvíli v Č́R př́liš aktuální. Tento stav se ale může relativně rychle změnit, což vyžaduje zvýšenou pozornost zodpovědných orgánů a institucí. Zároveň však na bedrech zodpovědných orgánů a institucí leží i pomoc $\mathrm{s}$ úspěšnou integrací přistěhovalců do většinové společnosti a prevence před vznikem xenofobních nálad ve společnosti, což rovněž představuje hrozbu.

Na základě analýzy autorem nashromážděných zdrojů lze říci, že došlo k potvrzení hypotézy vyřčené v samotném úvodu tohoto článku, tedy že Iráčané žijící v České republice nepředstavují závažnou bezpečnostní hrozbu pro národní bezpečnost České republiky.

\section{POZNÁMKY}

\footnotetext{
${ }^{1}$ Komunita Iráčanů je blíže představena v kapitole Iráčané žijicí v České republice a jejich integrace do české společnosti, kde se autor snaží čtenáři tuto zajímavou minoritu ve stručnosti co nejlépe přiblížit. Využívá zde při tom nejenom uvedených zdrojů, ale i vlastních poznatků.

${ }^{2}$ SCHEINOST, Miroslav, Trestná činnost cizinců a možné vlivy migračních procesů na kriminalitu v ČR [online], s. 17.

${ }^{3}$ ANGENENDT, Steffen, International Migration - Just a Matter of State Security? [online], s. 20.

${ }^{4}$ ZEMAN, Petr, Česká bezpečnostní terminologie, s. 85-94.

${ }^{5}$ Rozhovory s Iráčany byly vedeny převážně v Praze a Brně a byl kladen důraz na pokud možno co největší zastoupení všech etnických a náboženských skupin žijících v Iráku, stejně tak jako na zahrnutí respondentů pobývajících v České republice různě dlouhou dobu. Celkem bylo uskutečněno jedenáct rozhovorů, přičemž respondentům byl krátce představen účel rozhovoru. Respondenti následně odpovídali na předem prripravené otázky věnující se důvodu a době jejich příchodu do České republiky (Československa), jejich životu v České republice atp.

${ }^{6}$ HUYSMANS, Jeff, The European Union and the securitization of Migration, s. 761.

${ }^{7} \mathrm{~V}$ práci se objevuje pojem extremismus, přičemž v rámci tohoto textu je chápán v souladu s pojetím pracovní definice Ministerstva vnitra, kdy jsou jako extremismus označovány vyhraněné ideologické postoje, které vybočují z ústavních, zákonných norem, vyznačují se prvky netolerance a útočí proti základním demokratickým ústavním principům, jak jsou definovány v českém ústavním pořádku (Co je extremismus, [online]).

${ }^{8}$ BOSSWELL, Christina, The Securitization of Migration: A Risky Strategy for European States[online], s. 1.

${ }^{9}$ BUREŠ, Jaroslav, Main Characteristic and Development Trends of Migration in the Arab World, s. 11.

${ }^{10}$ SÜSSMUTH, Rita, Migration - High Time for New Thinking, [online], s. 14.

${ }^{11}$ KICINGER, Anna, International Migration as a Non-Traditional Security Threat and the EU Responses to This Phenomenon, [online], s. 2.

${ }^{12}$ KICINGER, Anna, International Migration as a Non-Traditional Security Threat and the EU Responses to This Phenomenon, [online], s. 2-3; ANGENENDT, Steffen, International Migration - Just a Matter of State Security? [online], s. 20-21.

${ }_{13}$ DRBOHLAV, Dušan, Mezinárodní migrace v Česku s důrazem na legální pracovní migraci, s. 57-62; BARŠOVÁ, Andrea, BARŠA, Pavel, Přistěhovalectví a liberální stát: imigrační politiky v západní Evropě a Česku, s. 218.

${ }^{14} Z$ práva o situaci v oblasti migrace na území České republiky za rok 2007 [online].

${ }^{15}$ Cizinci podle pobytu, pohlaví a státního občanství - k 30. 4. 2009, [online].
} 
${ }^{16}$ BUREŠ, Jaroslav, Main Characteristic and Development Trends of Migration in the Arab World, s. 161.

${ }^{17}$ Cizinci podle pobytu, pohlaví a státního občanství - k 30. 4., [online].

${ }^{18}$ Osobám, které nesplňují přísnou definici právního postavení uprchlíka, ale které mají prokazatelnou potřebu ochrany, může být poskytnuta tzv. doplňková ochrana. Ta vedle azylu představuje samostatnou formu mezinárodní ochrany, oproti azylu ji orgány České republiky poskytují pouze na dobu určitou (Základní pojmy a otázky spojené s migrací a azylem, [online]).

${ }_{19}$ Aktuálně platné azyly - 10 nejčastějších státních občanství, [online].

${ }^{20}$ Úspěšnost žadatelů o mezinárodní ochranu podle státních občanství; 1993-2007, [online].

${ }^{21}$ Statistická zpráva - Žadatelé o mezinárodní ochranu a azylanti, [online].

${ }^{22}$ Doplňková ochrana je ovšem udělována pouze na určitou dobu.

${ }^{23}$ O udělení víza České republiky požádalo v roce 2006 celkem 1452 Iráčanů a v roce 2007 jich bylo 1325. Zatímco v roce 2006 jej obdrželo 1135 osob (tj. 78, $1 \%$ ) o rok později již jen 856 osob (64,6 \%) (Zpráva o situaci v oblasti migrace na území České republiky za rok 2007, [online]).

${ }^{24}$ I dnes je možné na českých vysokých školách nalézt studenty z Iráku, již se ale jedná o jednotlivce. V rámci rozvojové pomoci zde nyní studují čtyři studenti (Dům zahraničních služeb MŠMT).

${ }^{25}$ ZÍDEK, Petr, SIEBER, Karel, Československo a blízký východ, s. 319.

${ }^{26}$ Rozhovor s M. Alrawim.

${ }^{27}$ Důvody se mohou lišit. Někteří již považují Českou republiku za svůj jediný domov, u jiných došlo k odcizení Iráku v souvislosti se spojeneckou invazí: „do roku 2001 jsem doufal, že se do Iráku vrátím a budu tam žít s rodinou, dnes již ne, jsem z bývalého Iráku, není kam se vracet (...) dlouho nebude možné se kam vracet" (rozhovor s M. Alrawim).

${ }^{28}$ Rozhovor s respondentem, Iráčanem, který přišel do ČR před dvěma roky a jenž si nepřál být konkrétně jmenován. Autor textu ovšem jeho identitu zná.

${ }^{29}$ TOPINKA, Daniel, Výzkumná zpráva. Integrační proces muslimů v České republice - pilotní projekt, s. 80.

${ }^{30}$ Viz rozhovor s S. Tomou.

${ }^{31}$ Rozhovor s M. Alrawim a rozhovor s respondentem, který si neprál uvést svou identitu (ta je ovšem autorovi známa).

${ }^{32}$ SCHEINOST, Miroslav, Trestná činnost cizinců a možné vlivy migračních procesů na kriminalitu v ČR [online], s. 12.

${ }^{33}$ Tamtéž.

${ }^{34}$ KICINGER, Anna, International Migration as a Non-Traditional Security Threat and the EU Responses to This Phenomenon, [online], s. 2-3.

${ }^{35}$ Srovnej TOPINKA, Daniel, Výzkumná zpráva. Integrační proces muslimů v České republice - pilotní projekt, s. 49 a SCHNEIDER, Jiří, Muslim Minorities and Czech Society [online], s. 132.

${ }^{36}$ Islám a jeho nebezpečí pro Evropu [online].

${ }^{37}$ Výroční zpráva Bezpečnostní informační služby za rok 2006 [online].

${ }^{38}$ DRBOHLAV, Dušan, Mezinárodní migrace v Česku s důrazem na legální pracovní migraci, s. 36-38.

${ }^{39}$ KICINGER, Anna, International Migration as a Non-Traditional Security Threat and the EU Responses to This Phenomenon, [online], s. 2.

${ }^{40}$ Jedná se o výzkum Názory české veřejnosti na cizince v České republice realizovaný Centrem pro výzkum veřejného mínění Sociologického ústavu Akademie věd ČR počátkem března roku 2009 (Názory české veřejnosti na cizince v České republice [online]).

${ }^{41}$ Zpráva o situaci v oblasti migrace na území České republiky za rok 2007 [online].

${ }^{42}$ Zločinné spolčení je podle ustanovení $§ 89$ odst. 20 (nyní odst. 17) tr. zák. společenstvím více osob s vnitřní organizační strukturou, s rozdělením funkcí a dělbou činností, které je zaměřeno na soustavné páchání úmyslné trestné činnosti (SCHEINOST, Miroslav, DIBLÍKOVÁ, Simona, Zločinné spolčení z pohledu České republiky - právní rámec, definice, postih, pachatelé s. 64).

${ }^{43}$ Policie rozbila gang, který vozil uprchlíky na Západ [online].

${ }^{44}$ Rozhovor s pplk. M. Ratajským, ÚOOZ PČR.

${ }^{45}$ CEJP, Martin, Organizovaný zločin očima expertů [online], s. 87.

${ }^{46}$ Dotazovaný si nepřál uvést svou identitu.

${ }^{47}$ Rozhovor s pplk. M. Ratajským, ÚOOZ PČR.

${ }^{48}$ Výroční zpráva Bezpečnostní informační služby za rok 2007 [online].

${ }^{49}$ BALOUN, Vladimír, Nejzávažnější rizika pro ČR - terorismus [online], s. 135.

${ }^{50}$ Národní akční plán boje proti terorismu. Aktualizované znění na léta 2007-2009 [online], s. 4. 
${ }^{51}$ Výroční zpráva Bezpečnostní informační služby za rok 2006 [online].

${ }^{52}$ BUREŠ, Jaroslav, Česká zahraniční politika vůči Středomoří a Blízkému východu, s. 134.

${ }^{53}$ Rozhovor s pplk. Ratajským, ÚOOZ PČR.

${ }^{54}$ Rozhovor s M. Alrawim.

${ }_{56}^{55}$ Rozhovor s respondentem, který si nepřál uvést svou identitu (ta je ovšem autorovi známa).

${ }^{56}$ Rozhovor s M. Alrawim a rozhovor s respondentem, který si nepřál uvést svou identitu (ta je ovšem autorovi známa).

\section{LITERATURA}

\section{Primární zdroje}

[1] Aktuálně platné azyly - 10 nejčastějších státních občanství [online]. Český statistický úřad, 2008 [cit. 2009-05-20]. 1 s. Dostupný z <http://www.czso.cz/csu/cizinci.nsf/t/690038ADF5/\$File/c03t17.pdf >.

[2] Cizinci podle pobytu, pohlaví a státního občanství - k 30. 4. 2009 [online]. Český statistický úřad, 2009 [cit. 2009-05-20]. 3 s. Dostupný z WWW: <http://www.czso.cz/csu/cizinci.nsf/t/B400494439/\$File/c01t01.pdf >.

[3] Co je extremismus [online]. Portál Ministerstva vnitra ČR, 2009 [cit. 2009-11-29]. Dostupný z WWW: <http://Www.mvcr.cz/clanek/co-je-extremismus.aspx>.

[4] E-mail od Ing. Mileny Navarové, Dům zahraničních služeb, Ministerstvo školství, mládeže a tělovýchovy České republiky (21. dubna 2009).

[5] E-mail od Ivany Bezuchové, Odbor všeobecné správy, oddělení státního občanství a matrik, Ministerstvo vnitra České republiky (13. května 2009).

[6] E-mail od Jiřího Beneše, Odbor bezpečnostní politiky, Ministerstvo vnitra České republiky (14. dubna 2009).

[7] E-mail od Mgr. Petra Hlaváčka, Odbor azylové a migrační politiky, Ministerstvo vnitra České republiky (11. května 2009).

[8] Informace o Irácké republice [online]. Velvyslanectví České republiky v Bagdádu, 2009 [cit. 2009-05-20]. Dostupný < http://www.mzv.cz/baghdad/cz/informace_o_iracke_republice/index.html>.

[9] Islám a jeho nebezpečí pro Evropu [online]. Dělnická strana, 2008 [cit. 2009-05-20]. Dostupný $\quad \mathrm{z} \quad$ WWW: $\quad<$ http://www.delnickastrana.cz/index.php?option=com_content\&task=view\&id=124\&Itemid=103>.

[10] Národní akční plán boje proti terorismu. Aktualizované znění na léta 2007-2009 [online]. Ministerstvo vnitra ČR, 2008 [cit. 2009-05-20]. 31 s. Dostupný z WWW: < http://web.mvcr.cz/archiv2008/dokument/2008/nap_2007_cze.pdf>.

[11] Názory české veřejnosti na cizince v České republice [online]. Centrum pro výzkum veřejného mínění AV ČR, 2009 [cit. 2009-05-20]. 4 s. Dostupný z WWW: <http://www.cvvm.cas.cz/upl/zpravy/100913s_ov90518.pdf >.

[12] Statistická zpráva - Žadatelé o mezinárodní ochranu a azylanti [online]. Ministerstvo vnitra České republiky, 2009 [cit. 2009-05-20]. Dostupný z WWW: <http://www.mvcr.cz/clanek/statisticke-zpravy-o-mezinarodni-ochrane-za-rok-2008.aspxpdf $>$.

[13] TOPINKA, Daniel, Výzkumná zpráva. Integrační proces muslimů v České republice pilotní projekt [online]. VeryVision, 2007 [cit. 2009-05-20]. 101 s. Dostupný z WWW: < http://web.mvcr.cz/archiv2008/dokument/2007/integrace_muslimu.pdf >. 
[14] Úspěšnost žadatelů o mezinárodní ochranu podle státních občanství; 1993-2007 [online]. Český statistický úřad, 2008 [cit. 2009-11-29]. Dostupný z WWW: <http://www.czso.cz/csu/cizinci.nsf/t/09002E0A05/\$File/c03r05.pdf>.

[15] Výroční zpráva Bezpečnostní informační služby za rok 2006 [online]. Bezpečnostní informační služba, 2007, [cit. 2009-05-20]. Dostupný z WWW: <http://www.bis.cz/n/200809-25-vyrocni-zprava-2007.html>.

[16] Výroční zpráva Bezpečnostní informační služby za rok 2007 [online]. Bezpečnostní informační služba, 2008, [cit. 2009-05-20]. Dostupný z WWW: <http://www.bis.cz/n/200809-25-vyrocni-zprava-2007.html>.

[17] Zpráva o situaci v oblasti migrace na území České republiky za rok 2007 [online]. Ministerstvo vnitra ČR, 2008 [cit. 2009-05-20]. 223 s. Dostupný z WWW: $<$ http://www.mvcr.cz/clanek/migracni-a-azylova-politika-ceske-republiky470144.aspx?q=Y2hudW09NA\%3D\%3D>.

\section{Rozhovory}

[18] Muneeb Alrawi, obchodník, předseda Ústředí muslimských obcí, (Brno, 11. 5. 2009).

[19] Sadik Toma, podnikatel, člen Iráckého fóra, Praha, 4. dubna 2009.

[20] Pplk. Michal Ratajský, důstojník, Útvar na odhalování organizovaného zločinu Policie ČR, Brno, 18. 5. 2009.

[21] Dva respondenti (zástupci komunity Iráčanů) si nepřáli publikovat svou identitu, ta je však autorovi známa.

\section{Sekundární zdroje}

\section{Knižní zdroje}

[22] BARŠOVÁ, Andrea, BARŠA, Pavel. Přistěhovalectví a liberální stát: imigrační politiky v západní Evropě a Česku. Brno : MPÚ, 2005. 308 s. ISBN 8021038756.

[23] BUREŠ, Jaroslav. Česká zahraniční politika vůči Středomoří a Blízkému východu. In PICK, Otto, HANDL Vladimír. Zahraniční politika České republiky 1993 - 2004 Úspěchy, problémy a perspektivy. Praha : Ústav mezinárodních vztahů, 2004. s. 121-142. ISBN 8086506398.

[24] BUREŠ, Jaroslav, Main Characteristic and Development Trends of Migration in the Arab World. Praha : Ústav mezinárodních vztahů, 2008. 176 s. ISBN 9788086506715.

[25] DRBOHLAV, Dušan. Mezinárodní migrace v Česku s důrazem na legální pracovní migraci. In DRBOHLAV, Dušan. Nelegální ekonomické aktivity migrantũ. (Česko v evropském kontextu.) Praha : Karolinum, 2008. s. 57-63. ISBN 9788024615523.

[26] ZEMAN, Petr, Česká bezpečnostní terminologie. Brno : MPÚ, ÚSS VA, 2002. 186 s. ISBN 8021030372 .

[27] ZÍDEK, Petr, SIEBER, Karel. Československo a Blizký východ v letech 1948-1989, Praha : ÚMV, 2009. 394 s. ISBN 4949788086506760.

\section{Periodika a elektronické texty}

[28] ANGENENDT, Steffen, International Migration - Just a Matter of State Security? In SOMMER, Jerry, WARNECKE, Andrea. The Security - Migration Nexus Challenges and Opportunities of African Migration to EU Countries [online]. Bonn, BICC, 2008 
[cit. 2009-05-20]. $\quad$ s. 19-21. Dostupný z < http://www.bicc.de/uploads/pdf/publications/briefs/brief36/brief36.pdf >.

[29] BALOUN, Vladimír, Nejzávažnější rizika pro ČR - terorismus. In CEJP, Martin. Obrana proti ohrožení společnosti závažnými formami trestné činnosti [online]. Praha, Institut pro kriminologii a sociální prevenci, 2008 [cit. 2009-05-20]. s. 119-137. Dostupný z WWW: < http://www.ok.cz/iksp/docs/353.pdf >.

[30] BOSWELL, Christina, The Securitization of Migration: A Risky Strategy for European States [online]. Danish Institute for International Studies, 2007 [cit. 2009-05-20]. 6 s. Dostupný z WWW:

<http://www.diis.dk/graphics/Publications/Briefs2007/boswell_securitisation_of_migration. pdf $>$.

[31] CEJP, Martin, Organizovaný zločin očima expertů. In CEJP, Martin. Obrana proti ohrožení společnosti závažnými formami trestné činnosti [online]. Praha, Institut pro kriminologii a sociální prevenci, 2008 [cit. 2009-05-20]. s. 80-102. Dostupný z WWW: < http://www.ok.cz/iksp/docs/353.pdf >.

[32] HUYSMANS, Jeff, The European Union and the securitization of Migration. Journal of Common Market Studies. 2000, roč. 38, č. 5, s. 751-777.

[33] KICINGER, Anna, International Migration as a Non-Traditional Security Threat and the EU Responses to This Phenomenon [online], Warsaw, Central European Forum For Migration Research, 2004 [cit. 2009-05-20]. Dostupný z <http://www.cefmr.pan.pl/docs/cefmr_wp_2004-02.pdf >.

[34] Policie rozbila gang, který vozil uprchlíky na Západ. Idnes.cz [online], 2007 [cit. 2009-0520]. Dostupný z WWW: < http://zpravy.idnes.cz/policie-rozbila-gang-ktery-vozil-uprchlikyna-zapad-fyd-/krimi.asp?c=A070516_112640_krimi_miz >.

[35] SCHEINOST, Miroslav, Trestná činnost cizinců a možné vlivy migračních procesů na kriminalitu v ČR. In CEJP, Martin. Obrana proti ohrožení společnosti závažnými formami trestné činnosti [online]. Praha, Institut pro kriminologii a sociální prevenci, 2008 [cit. 2009-05-20]. s. 10-60. Dostupný z WWW: 〈http://www.ok.cz/iksp/docs/353.pdf >.

[36] SCHEINOST, Miroslav, DIBLÍKOVÁ, Simona, Zločinné spolčení z pohledu České republiky - právní rámec, definice, postih, pachatelé. In CEJP, Martin. Obrana proti ohrožení společnosti závažnými formami trestné činnosti [online]. Praha, Institut pro kriminologii a sociální prevenci, 2008 [cit. 2009-05-20]. s. 61-79. Dostupný z WWW: <http://www.ok.cz/iksp/docs/353.pdf >.

[37] SCHNEIDER, Jiř́, Muslim Minorities and Czech Society. In KILPALDI, Pamela. Islam and Tolerance in Wider Europe [online], Budapest, New York, Open Society Institute, 2007. [cit. 2009-05-20]. s. 131-135. Dostupný z WW: <http://www.policy.hu/news/PPtoc>.

[38] SÜSSMUTH, Rita, Migration - High Time for New Thinking In SOMMER, Jerry, WARNECKE, Andrea. The Security - Migration Nexus Challenges and Opportunities of African Migration to EU Countries [online]. Bonn, BICC, 2008 [cit. 2009-05-20]. s. 14-17. Dostupný WWW: < http://www.bicc.de/uploads/pdf/publications/briefs/brief36/brief36.pdf >.

[39] Základní pojmy a otázky spojené s migrací a azylem, [online]. UNHCR - Uprchlíci v České republice [cit. 2009-05-20]. Dostupný z WWW: $<$ http://www.unhcr.cz/uprchlicicr/?cid=508>. 